\title{
Achieving LDL target reduces intensity of periprocedural myonecrosis
}

\author{
Helena Jerkić*, \\ Mario Stipinović, \\ Stjepan Kranjčević, \\ Damir Kozmar, \\ Darko Počanić, \\ Tomislav Letilović \\ Clinical Hospital Merkur, \\ Zagreb, Croatia
}

RECEIVED:

July 15, 2015

ACCEPTED:

September 17, 2015

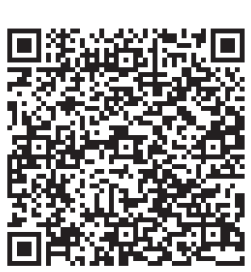

口 Cardiologia Croatica 2015;10(9-10):236.
KEYWORDS: stabile coronary disease, periprocedural myonecrosis, lipid parameters.

CITATION: Cardiol Croat. 2015;10(9-10):236. | DOI: http://dx.doi.org/10.15836/ccar.2015.236

*ADDRESS FOR CORRESPONDENCE: Helena Jerkić, Clinical Hospital Merkur, Zajčeva 19, HR-10000 Zagreb, Croatia. Phone: +385-1-2461-390 / E-mail: helenajerkic@yahoo.com

ORCID: Helena Jerkić, http://orcid.org/0000-0002-1650-4735 • Mario Stipinović, http://orcid.org/0000-0002-1582-1552 Stjepan Kranjčević, http://orcid.org/0000-0002-1575-1902 • Damir Kozmar, http://orcid.org/0000-0001-7626-3534 Darko Počanić, http://orcid.org/0000-0003-3257-110X • Tomislav Letilović, http://orcid.org/0000-0003-1229-7983

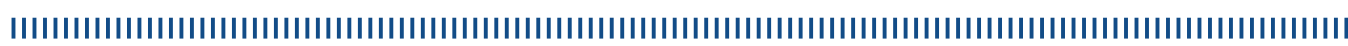

Statin treatment, applied before percutaneous coronary intervention (PCI), was shown to reduce periprocedural myocardial damage and overall MACE. ${ }^{1}$ Most of the studies showing such relation were done in statin naïve patients. In the only study that was done in statin treated patients, overall population did not reach proposed LDL target i.e. $<1.8 \mathrm{mmol} / \mathrm{L}$. Reaching that target is a measure of adequate statin treatment in everyday practice. We hypothesized that achieving LDL target, i.e. applying adequate statin treatment, could reduce periprocedural myonecrosis in patients with stabile coronary disease scheduled for elective PCI.

Data from 372 patients, in a period of 16 months, were collected. Values of troponin I were measured before the procedure as well as 8 and 16 hours after the procedure. Lipid parameters were determined before the procedure. Intensity of periprocedural myonecrosis was measured as a difference between troponin I values before the procedure and the values 8 and 16 hours after the procedure. Statin reload was not applied. In patients reaching LDL target (114 patients) intensity of periprocedural myonecrosis was lower both at 8 hours $(p=0,038)$ as well as at 16 hours $(p=0,013)$ after the procedure when compared to patients that did not reach LDL (258 patients) target. When statin naïve patients were excluded from the analysis the same difference, between patients reaching LDL target (104 patients) and those that did not reach it $(204$ patients) both at 8 hours $(p=0,028)$ as well as at 16 hours $(p=0,003)$ after the procedure, could be observed. In a multiple regression analysis only LDL levels significantly $(p=0,003)$ correlated with intensity of periprocedural damage. No such correlation was found for other lipid parameters, CRP or creatinine.

Our results show that reaching LDL target reduces myocardial damage during PCI. Such a relation could imply a need for a more stringent adherence to LDL target in patients undergoing elective PCI procedures.



1. Patti G, Cannon CP, Murphy SA, Mega S, Pasceri V, Briguori C, et al. Clinical benefit of statin pretreatment in patients undergoing percutaneous coronary intervention: a collaborative patient-level meta-analysis of 13 randomized studies. Circulation. 2011;123(15):1622-32. DOI: http://dx.doi.org/10.1161/CIRCULATIONAHA.110.002451. 